\title{
Bibliographie restreinte
}

Jean-Marie Maguin et Patricia Dorval

\section{(2) OpenEdition \\ Journals}

Édition électronique

URL : http://journals.openedition.org/shakespeare/1011

DOI : 10.4000/shakespeare.1011

ISSN : 2271-6424

Éditeur

Société Française Shakespeare

Édition imprimée

Date de publication : 1 novembre 1998

Pagination : 205-207

ISBN : 2-84269-230-6

Référence électronique

Jean-Marie Maguin et Patricia Dorval, «Bibliographie restreinte », Actes des congrès de la Société

française Shakespeare [En ligne], 16 | 1998, mis en ligne le 01 novembre 1999, consulté le 19 avril 2019. URL : http://journals.openedition.org/shakespeare/1011 ; DOI : 10.4000/shakespeare.1011 


\section{S H A K E S P E A R E \\ \& $\quad$ L E $\quad$ C I N É M A}

Société Française Shakespeare

Actes du Congrès de 1998

米 $*$ *

Textes réunis et présentés par

Patricia DORVAL

publiés sous la direction de

Jean-Marie MAGUIN 
Site web : <http : //alor.univ-montp3.fr/serinf/SFS/> Liste de diffusion : <sfs-1@smrl.univ-montp3.fr >

Tous droits de traduction, de reproduction et d'adaptation réservés pour tous les pays.

(C) 1998. Société Française Shakespeare,

École Normale Supérieure, 45 rue d'Ulm. 75005 Paris.

ISBN 2-84269-230-6 


\section{B I BLIOG R P H IE RES TREIN TE}

BALL, Robert Hamilton, Shakespeare on Silent Film : A Strange Ev'entful History, London, George Allen and Unwin, 1968.

BOOSE, Lynda E. \& BURT, Richard (eds.), Shakespeare: The Movie, London, Routledge, 1997.

BUCHMAN, Lorne M., Still in Movement: Shakespeare on Screen, London and New York, Oxford University Press, 1991.

BULMAN, James C. \& COURSEN Herbert R. (eds.), Shakespeare on Television: An Anthology of Essays and Reviews, Hanover, New Hampshire, University Press of New England, 1988.

COLLICK, John, Shakespeare, Cinema, Society, 'Culural Politics' Collection, Manchester, Manchester University Press, 1989.

COURSEN, Herbert R., Watching Shakespeare on Television, London and Toronto, Fairleigh Dickinson University Press and Associated University Presses, 1993.

CROWLE, Samuel, Shakespeare Observed : Studies in Performance on Stage and Screen, Athens, U.S.A., Ohio University Press, 1992.

DAVIES, Anthony, Filming Shakespeare's Plays: The Adaptations of Laurence Olivier, Orson Welles, Peter Brook and Akira Kurosawa, Cambridge, Cambridge University Press, 1988.

DAVIES, Anthony \& WELLS, Stanley, Shakespeare and the Moving Image (The Plays on Film and Television), Cambridge, Cambridge University Press, 1994.

DONALDSON, Peter S. (ed.), Shakespearean Films / Shakespearean Directors, Boston, Unwyn Hyman, 1990.

DORVAL, Patricia, Rhétorique et représentation: Les Figures de 
l'absence et l'imaginaire shakespearien, thèse de doctorat, Montpellicr, 1994 (microfiches disponibles dans les Bibliothèques Universitaires).

—, «Shi:kespeare on Screen» (vidéographie), Cahiers Elisabéthains, $\mathrm{n}^{\circ} 53,1998$, p. 53-75.

- «Shakespeare and the Multimedia: The C.E.R.R.A. Video Library», publication électronique, World-Wide Web, http : //serinf2.univmontp3.fr/CERRA/ Shakespeare_Multimedia/.

ECKERT, Charles W. (ed.), Focus on Shakesperean Films, Englewood Cliffs, Prentice Hall, 1968.

FRANCE, Richard, The Theatre of Orson Welles, London, Associated University Presses, 1977.

GRANT, Cathy (ed.), 'As You Like It': Audiovisual Shakespeare, London, British Universities Film and Video Council, 1992.

HOLDERNESS, Graham \& MCCULLOUGH, Christopher, «Shakespeare on the Screen : A Selective Filmography», Shakespeare Survey, n³9, 1987, p. 13-37. Press, 1989.

-, The Taming of the Shrew, Manchester, Manchester University

JACKSON, Russell (ed)., Cambridge Companion to Shakespeare on Film, Cambridge University Press, 1999 (à paraître).

JORGENS, Jack J., «Shakespeare on Film : A Sclected Checklist», LF(), vol. $4, n^{\circ} 2,1976$, p. 191.3 .

—, Shakespeare on Film, London, Indiana University Press, 1977.

KLIMAN, Bernice W., Hamlet: Film, Television and Audio Performance, London, Associated University Presses, 1988.

KozINTSEV, Grigori, Shakespeare, Time and Conscience, London, Dennis Dobson, 1967.

-, King Lear: The Space of Tragedy, The Diary of a Film Director, London, Heinemann, 1977.

MCKERNAN, Luke \& TERRIS, Olwen (eds.), Walking Shadow's : Shakespeare in the National Film and Television Archive, London, British Film Institute, BFI Publishing, 1994.

MCLEAN, Andrew M., Shakespeare: Annotated Bibliographies and Media Guide for Teachers, Urbana, NCTE, 1980.

MANVELL, Roger, Shakespeare and the Film, London, J.M. Dent, 1979 (1971).

MORRIS, Peter (ed.), Shakespeare on Film, Ottawa, Canadian Film Institute, 1972.

PARKER, Barry M., The Folger Shakespeare Filmography: A Directory of Feature Films Based on the Works of William Shakespeare, Washington (D.C.), Folger Shakespeare Library, 1979.

PILKINGTON, Ace G., Screening Shakespeare from 'Richard II' to 
'Henry V', London, Associated University Presses, 1991.

ROSS, Harris, «William Shakespeare and Film», Film as Literature, Literature as Film. An Introduction to and Bibliography of Film's Relationship to Literature, New York, Greenwood Press, 1987, p. 209-30.

ROTHWELL, Kenneth S. \& MELZER, Annabelle. Henkin, Shakespeare on Screen: An International Filmography and Videography, London, Mansell, 1990.

SINYARD, Neil, Filming Literature: The Art of Screen Adaptation, London, Croom Helm, 1986.

SKOUMAND, Michael (ed.), Screen Shakespeare, Aarhus, Denmark, Aarhus University Press, 1994.

TERRIS, Olwen (ed.), Shakespeare: A List of Audio-Visual Materials Available in the $U K$, London, British Universities Film \& Video Council, 1985.

WARREN, Roger, Cymbeline, 'Shakespeare in Performance' Collection, Manchester, Manchester University Press, 1989.

WELLS, Stanley (ed.), Shakespeare Survey, ${ }^{\circ} 39$, Cambridge University Press, 1987.

WILLEMS, Michèle (éd.), Shakespeare à la télévision, Centre d'Études du Théâtre Anglo-Saxon, Publications de l'Université de Rouen, 1987.

WILLIS, Susan, The BBC Shakespeare Plays : Making the Televised Canon, Chapel Hill \& London, University of North Carolina Press, 1991.

Patricia DORVAL \& Jean-Marie MAGUIN Centre d'Études et de Recherches sur la Renaissance Anglaise Université Paul-Valéry - Montpellier III 